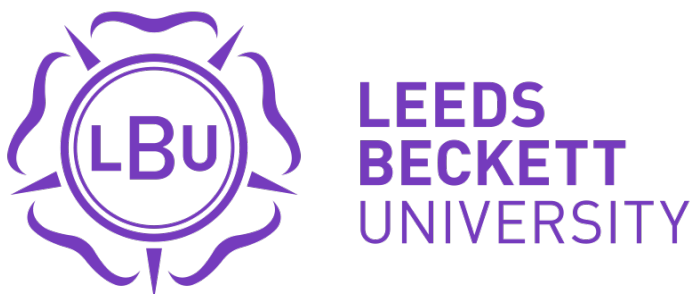

Citation:

Woodall, $J$ (2010) Exploring concepts of health with male prisoners in three category-C English prisons. International Journal of Health Promotion and Education, 48 (4). 115 - 122. ISSN 1463-5240 DOI: https://doi.org/10.1080/14635240.2010.10708194

Link to Leeds Beckett Repository record:

https://eprints.leedsbeckett.ac.uk/id/eprint/101/

Document Version:

Article (Accepted Version)

The aim of the Leeds Beckett Repository is to provide open access to our research, as required by funder policies and permitted by publishers and copyright law.

The Leeds Beckett repository holds a wide range of publications, each of which has been checked for copyright and the relevant embargo period has been applied by the Research Services team.

We operate on a standard take-down policy. If you are the author or publisher of an output and you would like it removed from the repository, please contact us and we will investigate on a case-by-case basis.

Each thesis in the repository has been cleared where necessary by the author for third party copyright. If you would like a thesis to be removed from the repository or believe there is an issue with copyright, please contact us on openaccess@leedsbeckett.ac.uk and we will investigate on a case-by-case basis. 


\section{Exploring concepts of health with male prisoners in three category-C English prisons}

Authors: James Woodall

Institution: Faculty of Health, Leeds Metropolitan University

Keywords: health promoting prison, lay perspectives, qualitative

Contact details for all correspondence:

James Woodall

Centre for Health Promotion Research

Leeds Metropolitan University

Faculty of Health

Room G08 Queens Square House

Civic Quarter

Leeds LS2 8AF

j.woodall@leedsmet.ac.uk

01138124436 


\title{
Exploring concepts of health with male prisoners in three category-C English prisons
}

\begin{abstract}
Lay understandings of health and illness have a well established track record and a plethora of research now exists which has examined these issues. However, there is a dearth of research which has examined the perspectives of those who are imprisoned. This paper attempts to address this research gap. The paper is timely given that calls have been made to examine lay perspectives in different geographical locations and a need to re-examine health promotion approaches in prison settings.
\end{abstract}

Qualitative data from thirty-six male sentenced prisoners from three prisons in England were collected. The data was analysed in accordance with Attride-Stirling's (2001) thematic network approach. Although the men's perceptions of health were broadly similar to the general population, some interesting findings emerged which were directly related to prison life and its associated structures. These included access to the outdoors and time out of their prison cell as well as maintaining relationships with family members through visits. The paper proposes that prisoners' lay views should be given higher priority given that prison health has traditionally been associated with medical treatment and the bio-medical paradigm more generally. It also suggests that in order to fulfil the World Health Organization's (WHO) vision of viewing prisons as health promoting settings, lay views should be recognised to shape future health promotion policy and practice. 


\section{Introduction}

Understanding the lay perspective of health and well-being has long been recognised (Herzlich, 1973; Cornwell, 1984; Blaxter, 2004). Lay understandings of health are often complex and multifaceted and often extend the views of medical or professional 'experts' (Entwistle et al., 1998). Tones and Green (2004), drawing on the work of Herzlich (1973), Blaxter and Patterson (1982), Williams (1983) and Cornwell (1984), identified key issues relating to lay understandings of health, these included: the absence of disease, a reserve for coping with stress and illness, functional ability to allow tasks to be performed and health as an ideal state which included positive wellbeing. A similar synthesis of world lay health views by Hughner and Kleine (2004) revealed eighteen themes, five of which were categorised as 'definitions of health'. Whilst research examining lay perspectives of health and illness has grown in recent times, surprising little work has been done to examine the views of those who are imprisoned. Indeed, a focus on this may be timely given that Hughner and Kleine (2004) have suggested that understanding lay views by geographical location would further our conceptual understandings. Moreover, the lay perspective may be imperative when examining health promotion efforts in prison, given that calls have been made to re-examine current approaches (Douglas et al., 2009).

Prisoners represent an ever increasing sub-group of the population. On an international level, there are more than 9.8 million people in penal institutions. Based on world population figures from the United Nations, this produces a world prison population rate of 145 per 100,000 of the population (Walmsley, 2009). Within England and Wales, approximately 83,000 offenders reside within prison establishments (Ministry of Justice, 2009), this equates to 151 per 100,000 of the population (International Centre for Prison Studies, 2009). The prison population in 
England and Wales has grown rapidly in recent years. Between 1995 and 2007, for example, the number of people in prison increased by 60 percent (Carter, 2007; Ministry of Justice, 2007). Estimates suggest that if recent sentencing trends continue the prison population could rise to over 98,000 by 2013 (de Silva et al., 2006). The overwhelming majority of prisoners are male with the average age of those being sentenced at 27 years (Prison Reform Trust, 2008; Ministry of Justice, 2009). However, the increase in the prison population has been proportionally greater among women, older and younger prisoners and people from minority ethnic groups (Caraher et al., 2002; Coyle and Stern, 2004; Levy, 2005; Condon et al., 2006; Jewkes, 2007).

However, despite the growth in the prison population and the recent partnership between the Prison Service and the National Health Service (NHS) which ensures that local Primary Care Trusts consider prisoners as part of the population for which they are responsible (Condon et al., 2006), there is a dearth of research literature on prisoners' involvement in prison health research (Sainsbury Centre for Mental Health, 2008). Hek (2006), for instance, has suggested that the prisoners' voice is often missing in published research. Furthermore, there has been a shortage of discussion on prisoners' concepts of health and illness, although some studies have focussed on the views of female prisoners. Smith's (2002) research, for example, in three female prisons in England, briefly revealed that in defining health respondents made links between food, diet and health. Similarly, in Plugge et al.'s (2008) study, many female prisoners viewed health as being related to individual actions, for example, what they ate, whether they exercised or took drugs. The authors suggested that the women saw health as a resource not just the absence of disease, concluding that imprisoned women's concepts of health were similar to lay people's views in the general community (Plugge et al., 2008). 
There is currently a drive towards seeing prisons as viable environments for health promotion. Since 1995, after a meeting organised by the WHO (1995), prisons have been regarded as key settings for health promotion. This momentum has continued to grow through the WHO's Health in Prisons Project which now has thirty-eight countries that are participating at a policy making level to reduce public health risks through improving health in prisons (Møller et al., 2009). Moreover, national policy drives, particularly in England and Wales (Department of Health, 2002; 2004; 2007; HM Prison Service, 2003) have been committed to the health promoting prisons movement.

Despite a lack of research, the WHO have been proponents of the importance of listening to the views of prisoners and prison staff in order to meet their needs through health promotion strategies (WHO, 1995). This paper is one of the few that have aimed to explore the ways in which 'health' is defined and constructed by male prisoners. The research took place in three category-C prisons in England and these findings formed part of a larger study which was concerned with the notion of a health promoting prison.

\section{Methodology}

Given the exploratory nature of the research a qualitative approach was employed. Using this approach allowed the subjective reality of the prison setting to be captured through prisoners' own individual experiences. This offered the opportunity to gather full and descriptive data concerning individuals' contexts. One-to-one in depth interviews and focus groups were conducted with convicted male prisoners all serving medium to long-term sentences in three category-C prisons in England. Category-C prisons contain those who cannot be trusted in open conditions but who 
do not have the ability or resources to attempt escape (Leech and Cheney, 2002). Category-C prisons contribute the largest proportion of the prison estate and tend to vary considerably in terms of size, date of construction, design and levels of security (Marshall, 1997; Creighton and King, 2000).

Accessing prisons is notoriously difficult and authors have consistently noted the difficulties in establishing research studies (Jupp, 1989; Hart, 1995; Bosworth, 1999; Martin, 2000; Davies, 2000; Smith and Wincup, 2000; 2002; King, 2000; Noaks and Wincup, 2004; Buckland and Wincup, 2004; King and Wincup, 2008). Access to the prisons for this study was negotiated through the Offender Health Research Network (OHRN). The OHRN are an organisation set up to create an environment of support, contact and capacity building among professionals interested in prison health care. They essentially functioned as a 'gatekeeper to the gatekeepers' (Noaks and Wincup, 2004) as they assisted the researcher in establishing contact with prison governors who were interested in areas of prison health research, particularly health promotion, and were able to facilitate appropriate levels of access. After initial contact had been made, several meetings were arranged with prison officials to outline the rationale for the study and the proposed methodological approach. Ultimately, a careful balance was struck between stringent practicalities, security and logistics of an 'outsider' working inside a prison (driven by the prisons) and the need to ensure robust and rigorous intellectual exploration and investigation of the phenomena (driven by the researcher).

In two of the establishments, residential areas (wings) were chosen to base recruitment materials. Wings were selected which could offer a potential sample of prisoners with a broad range of characteristics including demographic features, offence types, experiences of prison life (first time offenders, chronic recidivists) and sentence lengths. Wings were also chosen so that prisoners who have traditionally 
been excluded from studies based on their age, offence or status had the opportunity to participate. So, for example, two Vulnerable Prisoner Units (VPU) were selected; these wings predominantly accommodated older prisoners and those convicted of sexual offences. In the third prison, recruitment materials were predominantly located in the healthcare department of the prison and not in residential areas. This was due to the constraints put on the research by the prison governor. The limitation of this approach was recognised from the outset, as only those men accessing healthcare services would have been aware of the study. However, locating the recruitment materials in the healthcare department maintained the "maximum variation sample' (Sandelowski, 1995; Patton, 2002) that the researcher was requiring, as it allowed a diverse mix of prisoners to potentially take part in research activities. This allowed individuals with varying characteristics to participate in the study if they chose to.

Participants were recruited into the study using posters which were designed to draw attention to the study and provide some preliminary information as to its overall aims and general purpose. The poster also invited potential participants to inform a member of staff of their interest in the study. After reading the recruitment materials and informing a member of staff of their interest in the study, a total of thirty-six prisoners agreed to participate. These men were provided with participant information and provided written consent. Nineteen prisoners took part in one to one in-depth interviews lasting between one and two hours and a further seventeen prisoners participated in a total of four focus group discussions lasting, on average, one and a half hours. In many cases, the research was conducted in prison classrooms but always behind a closed door. In a few cases it was necessary for one-to-one interviews to be conducted in an individual's prison cell; once again, this was without the presence of any prison staff. 


\section{Ethical implications}

The ethical debates and associated discussions regarding prisoners as research participants has been recently undergoing somewhat of a revival (Pont, 2008). Space does not permit a detailed discussion of the considerations made to ensure this was an ethically robust study. Needless to say, prisoners are a vulnerable subsection of the population and it is obvious that extreme sensitivities are required when conducting research with this particular group (Smith and Wincup, 2002; Liamputtong and Ezzy, 2005). Ethical approval for this study was provided by an NHS Research Ethics Committee.

\section{Data analysis}

Although it has effectively become customary that qualitative interviews and focus groups are audio recorded for research purposes (Oliver, 2003), two prison governors (due to potential security concerns) did not permit recording equipment in their establishments. This is not uncommon for researchers and has been noted elsewhere (Noaks and Wincup, 2004; Schlosser, 2008). Where audio recording was prohibited during interviews, elements raised by participants were jotted down in the form of key words and phrases and written up in more detail immediately after the interview had finished. Nevertheless, where audio recording is permitted it can evoke particular meaning for those who come into contact with the criminal justice system, as offenders will have been tape recorded as part of providing evidence for a criminal investigation (Noaks and Wincup, 2004; Wilson, 2006). Due to this, even if audio equipment is allowed within the prison, it is not uncommon or unusual for interviewees to refuse to be audio recorded. However, in the prison where recording was allowed, all prisoners $(n=10)$ agreed to be recorded after providing written consent. 
The use of thematic networks, as advocated by Attride-Stirling (2001), was adopted as a systematic way of organising the analysis. Thematic network analysis is not necessarily a new approach, as it builds on key features which are predominant in other forms of qualitative data analysis. Nonetheless, the unique aspect of thematic network analysis is that it constructs web-like matrixes, offering insight into the researcher's explicit processes from generating interpretation and theory from text and transcripts. Thematic networks systematically organise basic themes into organising themes and then into overarching global themes which succinctly encapsulates aspects of the data. NVivo 7 software was used to aid the data analysis.

On the preliminary review of the data, codes to the transcripts and fieldnotes were applied (using NVivo). Codes were predominantly based on recurring concepts or salient issues which were discussed during data collection or through perceived areas of theoretical interest. From the list of tentative codes, basic themes were abstracted and categorised; this required time and a great deal of interpretative work, but eventually reduced the data into a more manageable set of discrete extracts. The basic themes which were identified were reviewed and, in some cases after a period of reflection, an original theme was not considered robust enough to constitute a theme in itself. However, once satisfied with the list of basic themes, these founded the basis of the thematic network and were applied back to the original transcripts and notes to re-classify and organise the data. These basic themes were then grouped and clustered based on shared or common issues and a broader organising theme was derived based on the key issues which underpinned these basic level themes.

\section{Ensuring validity: member checking}


Respondent validation or "member checking" (Mays and Pope, 2000, p.51), where participants are given the opportunity to comment on transcripts or fieldnotes prior to analysis, was used where possible. This is similar to procedures used in other qualitative research with prison populations (Lindberg, 2005; de Viggiani, 2007; Goulding, 2007; Waldram, 2007). However, it was recognised that prisoners are a transient and mobile group and may be released early or transferred to other establishments before the transcript can be returned. In this instance, the researcher was unable to guarantee that the participant would have the opportunity to check interview data. Only five prisoners were therefore able to examine the transcript data of their interviews. In all cases, the prisoners provided no feedback. However, as central themes from the study began to develop they were informally fed back to prisoners, prison staff and gatekeepers. Their appraisal of themes elicited over the fieldwork, offered a prime opportunity to clarify interpretations and understandings of the prison setting.

\section{Research findings}

Although details concerning a prisoner's offence, their social background and their previous criminal activity were not routinely covered, many men provided extensive autobiographical reflections. Those men who participated in the study ranged from twenty-two to seventy years of age and all were serving medium to long-term sentences. The participants' experiences of prison were varied; several were experiencing prison for the first time, whilst others had served a number of previous sentences. Several prisoners had served time in juvenile detention centres, borstals and young offender institutions in their adolescent and teenage years. On several occasions, participants offered details concerning their current criminal charge. Various forms of acquisitive crime were common, mainly in order to fund drug habits; 
the possession and dealing of drugs, attempted bodily harm and grievous bodily harm were also crimes regularly mentioned by participants. A large proportion of the men on the VPU were serving sentences because of sexually motivated criminal acts.

\section{Prisoners' concepts of health}

Prisoners' concepts of health were varied and not limited to definitions simply associated with the absence of illness. The men who participated in the study spoke openly and explicitly about their health and from the interviews and focus groups the following key themes emerged.

\section{The importance of positive mental health}

An individual's mental state was a key aspect of maintaining their health whilst in prison. Craig, for example, discussed the need to have mental clarity whilst in prison: "Being healthy for me right now is having a good sleep pattern and a healthy clear mind."

A prisoner's mental state was described as being innately fragile and could fluctuate relatively quickly in response to various features of prison life. So, for example, altercations with staff and the restrictiveness of the regime often demoted prisoners' mental health, whilst discussions and visits from family members often elevated the men's frame of mind. Whilst in contrast to aspects of physical health (reported later), mental health was seen as being more difficult to control and impossible to enhance by virtue of being imprisoned. Prisoners on the VPU commented that where aspects of mental health could be enhanced, i.e. through yoga, meditation and distracting the mind through reading, the impacts of these would often be short-term and often counteracted very quickly by factors that would demote mental well-being, such as 
bullying, violence and verbal harassment. These negative influences were reported to permeate much of prison life. Throughout data collection, prisoners frequently discussed the impact that the organisational culture would have on their mental health. Several prisoners found the process of adapting to their new environment extremely difficult and this could be a catalyst for suicidal intentions or thoughts. Chris, for example, commented:

"Sometimes you have bad days, but I cope well compared to other people. People can get quite stressed out about it all...I've seen people who go to pieces, wanting to fucking string themselves up and thinking that they can't handle this. Some people are like that."

\section{Freedom}

Several prisoners constructed concepts of health which were strongly associated with freedom and liberation. Drug dependant prisoners and those who were withdrawing from drugs, discussed freedom in a metaphorical sense describing health as being 'released' or unbounded from their drug and alcohol addiction. These prisoners suggested that 'health' primarily concerned remaining or striving to become drug free. More commonly, however, freedom was associated with the confinement of institutional life. Prisoners emphasised the need for sufficient time out of their cell and adequate access to the outdoors in order to feel in good health. All three prison settings were set in rural parts of England and their physical layouts were sprawled over a substantial area. This allowed prisoners to walk outdoors on a regular basis in order to get to and from workshops, education blocks or other specific departments. Many prisoners' experiences contrasted sharply with some of the inner-city prisons that individuals had previously encountered, where often the majority of time was spent within the institution with minimal access to the outdoors. Many men viewed their current prison as facilitating their health through its 
geographical location. Steve, for example, was complementary about his current prison and the access to the outdoors:

"This prison is great because it gives you the open air and the space, there's nothing more depressing than being stuck on the wing where the only way of getting off is going to the gym or the exercise yard."

\section{Strength and fitness}

Health for many prisoners was closely associated with fitness and this was a hugely prominent construct to emerge with many younger and middle-aged respondents. In many cases, the prison gym became an escape from the usual confined 'space' of the wing or cell. In some cases, a consistent theme for the attainment of physical prowess occurred throughout interviews. Maintaining regular bouts of both structured and unstructured physical exercise throughout the prisoners' sentence was significant for sustaining, and in a number of instances enhancing health. In some cases, an extreme fanaticism and bordering obsession with building, shaping and toning muscle formed a large part of the men's perspectives.

The notion of a 'prison body' emerged in interviews with several prisoners. Further examination of this theme with David revealed that the body was a salient resource for prisoners in demonstrating their ability to cope and displaying their masculinity. For some prisoners, improving health through fitness would be a way of improving physical form in order to appeal to the opposite sex once released. Prison deprived heterosexual relationships and forced prisoners into celibacy, therefore prisoners spoke about the importance of sexual fulfilment when released from prison. Sculpting the body in order to make it more appealing to the opposite sex was one such way of improving the likelihood of sexual fulfilment. Furthermore, dedicating the 
body to weight lifting could also provide protection whilst in the institution by providing an intimidating, muscular exterior. Paul, for instance, suggested:

“...you've got to keep fit to look after yourself, to defend yourself, you know what I mean, got to keep in shape."

\section{Functioning}

The issue of muscle building was reported far less frequently by older prisoners in relation to it being an important construct of their health whilst in prison. Older aged prisoners often related health with possessing the vigour and energy to carry out basic functions related to daily life. Some older men spoke about walking around the prison unaided or doing so without feeling breathless. Several respondents discussed health as performing tasks without feelings of physical discomfort.

\section{Social relationships}

For many prisoners, health was dependent upon the maintenance of family connections. The preservation of the family unit and continuation of relationships with friends outside in the community, were critical facets of some individuals' definition of health whilst in prison. Rob, for example, suggested that good relationships were crucial to health and well-being. These relationships consisted of both internal prison relationships with fellow prisoners and staff and external relationships with family and friends. Rob claimed that maintaining outside relationships whilst incarcerated improved the chance of remaining 'healthy' as it withheld his prior identity as a father and husband.

A number of prisoners, however, suggested how financial and geographical difficulties created difficulties when maintaining relationships with family and friends thus impinging on their health. According to the prisoners, some families and friends 
were simply unable to cover the costs needed to travel to the prison and others found transportation issues problematic especially as all three prison settings were based in rural environments with poor and sporadic transport links.

\section{Self-discipline}

Self discipline was an important aspect in many prisoners' views on health. Prison often fostered lethargy through extended periods of idle time when locked in the prison cell. Having the discipline to eat the right foods and exercise regularly whilst in prison were therefore critical components of health. Jim discussed the concept of discipline at some length; he felt that being disciplined was an important aspect of managing health whilst in prison:

"I'm well disciplined on the outside but even more so in here... I do discipline myself, I go to the gym two or three times a week, I do a lot of fitness training and stuff like that so I tend to try and look after myself...I don't eat all the stodgy food."

For several prisoners, being disciplined was the difference between being a healthy prisoner and being an unhealthy prisoner; discipline was essentially seen as preventing unhealthy practices such as eating an unbalanced diet or being physically inactive.

\section{Fear of death}

Older prisoners were more likely to relate health with the absence of illness and disease. Fearing death whilst in prison was one prominent issue which emerged. Older men were apprehensive at the thought of possible heart attacks, strokes and other serious conditions as they were ageing in the prison. Don feared serious illness and suggested that the thought of dying whilst inside was unbearable. As men aged in the system they recognised the increased probability of dying in prison, 
which for many of the sample was a situation which was unthinkable. These thoughts caused increased anxiety and stress. Furthermore, the concern of being immobile (because of a stroke or heart attack) and permanently trapped in the cell was perceived as a "double punishment" which few suggested that they would be able to deal with.

\section{Discussion}

Understanding the aspects that determine health is essential to being able to support, improve and promote it (McKague and Verhoef, 2003). Through building rapport, listening and by allowing a space in which men could articulate their views, the complexity of lay health beliefs of prisoners were uncovered. The prisoners' concepts of health largely reflected those found in the general population where holistic notions are reported rather than simply the absence of disease. Indeed, as Plugge et al. (2008) have noted, this should not be surprising given that most prisoners spend the majority of their lives in the community. So, for example, like findings derived from non-prison samples (Papadopoulos, 2000) mental states of well-being strongly influenced concepts of health. Similarly, and related to the older prisoners that participated in the research, health is often associated with being able to carry out daily functions. McKague and Verhoef (2003), for instance, revealed that among older people health was frequently defined as having some level of functional fitness. However, there were some specific issues concerning prisoners' concepts of health that were unique to prison life. Having access to the outdoors, for example, featured highly in prisoners' accounts. Likewise, social relationships, especially contact with family members, were intimately intertwined with prisoners' ideas around being healthy. This particular finding has been reported previously with adult 
prisoners and young offenders (Dixey and Woodall, 2009; Woodall, 2007; Woodall et al., 2009).

The importance of lay accounts is that they can provide a perspective on the relationship between individuals and the settings in which they live (Popay et al., 1998). This is of value in an environment such as a prison where there are disproportional rates of ill health and evidence of risk taking behaviour (Social Exclusion Unit, 2002). Robertson (2006) suggests that lay perceptions have been influential in supporting a cultural shift away from a bio-medical perspective towards a more holistic and integrated understanding of health and well-being. This kind of shift is of importance given that prison health has traditionally been associated with medical treatment and the bio-medical paradigm more generally (Sim, 1990). Indeed, previous research has raised questions about the definitions of health which are currently deployed in the prison environment (Smith, 2002).

Approaches to health, particularly health promotion, have developed considerably within prisons in England and Wales. The publication of 'Health Promoting Prisons: A Shared Approach' (Department of Health, 2002), for instance, legitimised and championed a health promotion focus in prison healthcare, advocating the prevention of deterioration in health as well as encouraging prisoners to adopt healthy behaviours (Condon et al., 2007). Furthermore, the introduction of a specific Prison Service Order (PSO 3200) on health promotion in 2003 (HM Prison Service, 2003) was a major breakthrough for health promotion as it provided a level of commitment to health within the offender management system (Baybutt et al., 2007). Nevertheless, despite these significant policy developments, the extent to which prisoners are involved in shaping health promotion and education interventions remains questionable. Research has demonstrated how the responsibility for health in prisons is predominantly controlled by health 'experts' such as nurses (Caraher et 
al., 2002; Baybutt, 2004). Although many have championed nursing as the most obvious professional body to take forward the health promotion movement (King, 1994), many nurses view health in the physical and biological context of negative health states of illness and disease as they occur within a biomedical model (Whitehead, 2009).

Smith (2002), however, has noted how often normative health need, i.e. expert opinion, has governed much prison health policy and planning. Indeed it is these 'experts' that often remain in control in the discourse of health promotion and education (Kelly and Charlton, 1995). Health promotion is not a value free discipline and its advocates would attest that it holds varying priorities and strategies (Smith, 2000). It may be argued that those advocates within a prison setting reinforce the dominance of the medical model despite claims for health and health promotion to be framed as a whole prison matter. However, there are clear benefits when prisoners are able to participate and articulate their views; most notably, it can improve prisoners' self-esteem, improve the running of institutions and can improve staff prisoner relationships (Solomon and Edgar, 2004). Despite this, Levenson and Farrant (2002) note that neither the Home Office or Prison Service have ensured that this participation is intrinsic to prison culture. Indeed, where prisoner involvement has emerged it is often sporadic and uneven and not consistent across the prison estate (Solomon, 2004; Solomon and Edgar, 2004).

\section{Conclusions}

Health promotion in prisons offers an opportunity to move away from exclusively dealing with acute illness towards focusing instead on enabling and empowering individuals to take more control over their health both during their time in prison and 
afterwards into their communities. This offers major public health benefits outside of the prison perimeter, as prisoners inevitably return back to society. If health promotion is to be effective in settings like prisons then it needs to be sensitive to the ways in which social structures are experienced by individuals (Watson et al., 1996). Bosworth et al. (2005) have noted that it can be difficult, without serving a sentence, to know what prison life is like; yet, this understanding is vital if we are to understand the relationship between individuals and the settings in which they live (Popay et al., 1998). Undoubtedly, there have been significant developments in the health promoting prison movement, but if the WHO are to fulfil their vision then understanding 'health' from the perspective of the prisoner must be prioritised.

Word count: 4,690

\section{References}

Attride-Stirling, J. (2001). Thematic networks: an analytic tool for qualitative research. Qualitative Research, 1, 385-405.

Baybutt, M. (2004). PSO 3200 health promotion baseline audit. Report of findings. Preston: University of Central Lancashire.

Baybutt, M., Hayton, P. \& Dooris, M. (2007). Prisons in England and Wales: an important public health opportunity. IN Douglas, J, Earle, S, Handsley, S, Lloyd, C \& Spurr, S (Eds.) A reader in promoting public health. Challenge and controversy. Milton Keynes: Open University Press.

Blaxter, M. (2004). Health, Cambridge: Polity Press.

Blaxter, M. \& Patterson, S. (1982). Mothers and daughters: a three generational study of health attitudes and behaviour, London: Heinemann.

Bosworth, M. (1999). Engendering resistance: agency and power in women's prisons, Aldershot: Ashgate. 
Bosworth, M., Campbell, D., Demby, B., Ferranti, S. M. \& Santos, M. (2005). Doing prison research: views from inside. Qualitative Inquiry, 11, 249-264.

Buckland, G. \& Wincup, E. (2004). Researching crime and criminal justice. IN Muncie, J \& Wilson, D (Eds.) Student handbook of criminal justice and criminology. London: Cavendish Publishing.

Caraher, M., Dixon, P., Hayton, P., Carr-Hill, R., McGough, H. \& Bird, L. (2002). Are health-promoting prisons an impossibility? Lessons from England and Wales. Health Education, 102, 219-229.

Carter, P. (2007). Securing the future. Proposals for the efficient and sustainable use of custody in England and Wales. London: Ministry of Justice.

Condon, L., Hek, G. \& Harris, F. (2006). Public health, health promotion and the health of people in prison. Community Practitioner, 79, 19-22.

Condon, L., Hek, G. \& Harris, F. (2007). A review of prison health and its implications for primary care nursing in England and Wales: the research evidence. Journal of Clinical Nursing, 16, 1201-1209.

Cornwell, J. (1984). Hard-earned lives: accounts of health and illness from East London, London, Routledge.

Coyle, A. \& Stern, V. (2004). Captive populations: prison health care. IN Healy, J \& McKee, M (Eds.) Accessing health care: responding to diversity. Oxford: Oxford University Press.

Creighton, S. \& King, V. (2000). Prisoners and the law, London: Butterworths.

Davies, P. (2000) Doing interviews with female offenders. IN Jupp, V, Davies, P \& Francis, P (Eds.) Doing criminological research. London: Sage.

de Silva, N., Cowell, P., Chow, T. \& Worthington, P. (2006). Home Office statistical bulletin. Prison population projections 2006-2013. London: Crown.

de Viggiani, N. (2007). Unhealthy prisons: exploring structural determinants of prison health. Sociology of Health \& IIIness, 29, 115-135. 
Department of Health (2002). Health promoting prisons: a shared approach. London: Crown.

Department of Health (2004). Choosing health: making healthier choices easier. London: The Stationary Office.

Department of Health (2007). Improving health-supporting justice: a consultation document. A strategy for improving health and social care services for people subject to the criminal justice system. London: Department of Health.

Dixey, R. \& Woodall, J. (2009). Moving on: an evaluation of the Jigsaw Visitors' Centre. Leeds: Centre for Health Promotion Research.

Douglas, N., Plugge, E. \& Fitzpatrick, R. (2009). The impact of imprisonment on health. What do women prisoners say? Journal of Epidemiology and Community Health, published online 23rd April, 2009. doi:10.1136/jech.2008.080713.

Entwistle, V. A., Renfrew, M. J., Yearley, S., Forrester, J. \& Lamont, T. (1998). Lay perspectives: advantages for health research. British Medical Journal, 316, 463-466.

Goulding, D. (2007). Recapturing freedom. Issues relating to the release of longterm prisoners into the community, Annandale: Hawkins Press.

Hart, C. B. (1995). A primer in prison research. Journal of Contemporary Criminal Justice, 11, 165-176.

Hek, G. (2006). Unlocking potential: challenges for primary health care researchers in the prison setting. Primary Health Care Research and Development, 7, 9194.

Herzlich, C. (1973). Health and illness, London: Academic Press.

HM Prison Service (2003). Prison Service Order (PSO) 3200 on health promotion. London: HM Prison Service.

Hughner, R. S. \& Kleine, S. S. (2004). Views of health in the lay sector: a compilation and review of how individuals think about health. Health, 8, 395-422. 
International Centre for Prison Studies (2009). Entire world - prison population rates per 100,000 of the national population. London: Kings College.

Jewkes, Y. (2007). Prisoners. IN Jewkes, Y (Ed.) Handbook on prisons. Cullompton: Willan Publishing.

Jupp, V. (1989). Methods of criminological research, London: Routledge.

Kelly, M. P. \& Charlton, B. (1995). The modern and postmodern in health promotion. IN Bunton, R, Nettleton, S \& Burrows, R (Eds.) The sociology of health promotion. London: Routledge.

King, P. M. (1994) Health promotion: the emerging frontier of nursing. Journal of Advanced Nursing, 20, 209-218.

King, R. D. (2000). Doing research in prisons. IN King, RD \& Wincup, E (Eds.) Doing research on crime and justice. Oxford: Oxford University Press.

King, R. D. \& Wincup, E. (2008). The process of criminological research. IN King, RD \& Wincup, E (Eds.) Doing research on crime and justice. 2nd ed. Oxford: Oxford University Press.

Leech, M. \& Cheney, D. (2002). Prisons handbook, Winchester: Waterside Press.

Levenson, J. \& Farrant, F. (2002). Unlocking potential: active citizenship and volunteering by prisoners. Probation Journal, 49, 195-204.

Levy, M. (2005). Prisoner health care provision: reflections from Australia. International Journal of Prisoner Health, 1, 65-73.

Liamputtong, P. \& Ezzy, D. (2005). Qualitative research methods, Oxford: Oxford University Press.

Lindberg, O. (2005). Prison cultures and social representations. The case of Hinseberg, a women's prison in Sweden. International Journal of Prisoner Health, 1, 143-161.

Marshall, S. (1997). Control in category C prisons, London: Home Office Research and Statistics Directorate. 
Martin, C. (2000). Doing research in a prison setting. IN Jupp, V, Davies, P \& Francis, P (Eds.) Doing criminological research. London: Sage.

Mays, N. \& Pope, C. (2000). Assessing quality in qualitative research. British Medical Journal, 320, 50-52.

McKague, M. \& Verhoef, M. (2003). Understandings of health and its determinants among clients and providers at an urban community health center. Qualitative Health Research, 13, 703-717.

Ministry of Justice (2007). Story of the prison population: 1995-2007. London: Ministry of Justice.

Ministry of Justice (2009). Prison population \& accommodation briefing for 5th June 2009. London: Ministry of Justice.

Møller, L., Gatherer, A. \& Dara, M. (2009). Barriers to implementation of effecctive tuberculosis control in prisons. Public Health, 123, 419-421.

Noaks, L. \& Wincup, E. (2004). Criminological research. Understanding qualitative methods, London, Sage.

Oliver, P. (2003). The student's guide to research ethics, Maidenhead: Open University Press.

Papadopoulos, I. (2000). An exploration of health beliefs, lifestyle behaviours, and health needs of the London-based Greek Cypriot community. Journal of Transcultural Nursing, 11, 182-190.

Patton, M. Q. (2002). Qualitative research \& evaluation methods, Thousand Oaks: Sage.

Plugge, E., Douglas, N. \& Fitzpatrick, R. (2008). Imprisoned women's concepts of health and illness: the implications for policy on patient and public involvement in healthcare. Journal of Public Health Policy, 29, 424-439.

Pont, J. (2008). Ethics in research involving prisoners. International Journal of Prisoner Health, 4, 184-197. 
Popay, J., Williams, G., Thomas, C. \& Gatrell, A. (1998). Theorising inequalities in health: the place of lay knowledge. Sociology of Health \& IIIness, 20, 619-644.

Prison Reform Trust (2008). Bromley briefings. Prison factfile. London: Prison Reform Trust.

Robertson, S. (2006). 'Not living life in too much of an excess': lay men understanding health and well-being. Health, 10, 175-189.

Sainsbury Centre for Mental Health (2008). A review of service user involvement in prison mental health research. London: Sainsbury Centre for Mental Health.

Sandelowski, M. (1995). Sample size in qualitative research. Research in Nursing \& Health, 18, 179-183.

Schlosser, J. A. (2008). Issues in interviewing inmates. Navigating the methodological landmines of prison research. Qualitative Inquiry, 14, 15001525.

Sim, J. (1990). Medical power in prisons, Milton Keynes: Open University Press.

Smith, C. (2000). 'Healthy prisons': a contradiction in terms? The Howard Journal of Criminal Justice, 39, 339-353.

Smith, C. (2002). Punishment and pleasure: women, food and the imprisoned body. Sociological Review, 50, 197-211.

Smith, C. \& Wincup, E. (2000). Breaking in: researching criminal justice institutions for women. IN King, RD \& Wincup, E (Eds.) Doing research on crime and justice. Oxford: Oxford University Press.

Smith, C. \& Wincup, E. (2002). Reflections on fieldwork in criminal justice institutions. IN Welland, T \& Pugsley, L (Eds.) Ethical dilemmas in qualitative research. Aldershot: Ashgate.

Social Exclusion Unit (2002). Reducing re-offending by ex-prisoners. London: Crown. Solomon, E. (2004). Criminals or citizens? Prisoner councils and rehabilitation. Criminal Justice Matters, 56, 24-25. 
Solomon, E. \& Edgar, K. (2004). Having their say: the work of prison councils. London: Prison Reform Trust.

Tones, K. \& Green, J. (2004). Health promotion. Planning and strategies, London: Sage.

Waldram, J. B. (2007). Everybody has a story: listening to imprisoned sexual offenders. Qualitative Health Research, 17, 963-970.

Walmsley, R. (2009). World prison population list (8th edn). London: International Centre for Prison Studies.

Watson, J., Cunningham-Burley, S., Watson, N. \& Milburn, K. (1996). Lay theorizing about 'the body' and implications for health promotion. Health Education Research, 11, 161-172.

Whitehead, D. (2009). Reconciling the differences between health promotion in nursing and 'general' health promotion. International Journal of Nursing Studies, 46, 865-874.

WHO (1995). Health in prisons. Health promotion in the prison setting. Summary report on a WHO meeting, London 15-17 October 1995. Copenhagen, WHO.

Williams, R. G. A. (1983). Concepts of health: an analysis of lay logic. Sociology, 17, 185-204.

Wilson, D. (2006). Some reflections on researching with young black people and the youth justice system. Youth Justice, 6, 181-193.

Woodall, J. (2007). Barriers to positive mental health in a Young Offenders Institution: a qualitative study. Health Education Journal, 66, 132-140.

Woodall, J., Dixey, R., Green, J. \& Newell, C. (2009). Healthier prisons: the role of a prison visitors' centre. International Journal of Health Promotion and Education, 47, 12-18. 